\title{
Correction to: Impacts of climate change on agriculture and household welfare in Zambia: an economy-wide analysis
}

\author{
Hambulo Ngoma ${ }^{1,2}$ D $\cdot$ Patrick Lupiya ${ }^{1} \cdot$ Mulako Kabisa $^{1} \cdot$ Faaiqa Hartley $^{3}$
}

Published online: 10 December 2021

(c) The Author(s) 2021

\section{Correction to: Climatic Change \\ https://doi.org/10.1007/s10584-021-03168-z}

The article Impacts of climate change on agriculture and household welfare in Zambia: an economy-wide analysis written by Hambulo Ngoma, Patrick Lupiya, Mulako Kabisa1 and Faaiqa Hartley, was originally published Online First without Open Access. After publication in volume 167, issue 3-4, page 1-20 the author decided to opt for Open Choice and to make the article an Open Access publication. Therefore, the copyright of the article has been changed to (C) The Authors 2021 and the article is forthwith distributed under the terms of the Creative Commons Attribution 4.0 International License, which permits use, sharing, adaptation, distribution and reproduction in any medium or format, as long as you give appropriate credit to the original author(s) and the source, provide a link to the Creative Commons licence, and indicate if changes were made. The images or other third party material in this article are included in the article's Creative Commons licence, unless indicated otherwise in a credit line to the material. If material is not included in the article's Creative Commons licence and your intended use is not permitted by statutory regulation or exceeds the permitted use, you will need to obtain permission directly from the copyright holder. To view a copy of this licence, visit http://creativecommons.org/licen ses/by/4.0.

Funding This research is funded by the Southern Africa - Towards Inclusive Economic Development (SATIED) project managed by the International Food Policy Research Institute (IFPRI), grant number [RA No. 2019X298.IAP]. We duly acknowledge funding from the CGIAR Collaborative Research Program on Water, Land and Ecosystems, and the CGIAR Collaborative Research Program on Policies, Institutions and

The original article can be found online at https://doi.org/10.1007/s10584-021-03168-z.

Hambulo Ngoma

h.ngoma@cgiar.org

1 Indaba Agricultural Policy Research Institute, Lusaka, Zambia

2 Present Address: International Maize and Wheat Improvement Center (CIMMYT), Harare, Zimbabwe

3 University of Cape Town, Cape Town, South Africa 
Markets through IFPRI. Additional funding to IAPRI was obtained from Swedish International Development Agency (SIDA) and the United States Agency for International Development (USAID) in Lusaka, Zambia.

Open Access This article is licensed under a Creative Commons Attribution 4.0 International License, which permits use, sharing, adaptation, distribution and reproduction in any medium or format, as long as you give appropriate credit to the original author(s) and the source, provide a link to the Creative Commons licence, and indicate if changes were made. The images or other third party material in this article are included in the article's Creative Commons licence, unless indicated otherwise in a credit line to the material. If material is not included in the article's Creative Commons licence and your intended use is not permitted by statutory regulation or exceeds the permitted use, you will need to obtain permission directly from the copyright holder. To view a copy of this licence, visit http://creativecommons.org/licenses/by/4.0/.

Publisher's note Springer Nature remains neutral with regard to jurisdictional claims in published maps and institutional affiliations. 